\title{
NON-NATIVE HELIX LUCORUM LINNAEUS, 1758 (GASTROPODA: EUPULMONATA: HELICIDAE) AFTER TWELVE YEARS IN PRAGUE, CZECH REPUBLIC
}

\author{
JIŘI DOLEŽAL
}

Verdunská 25, Praha 6, Czech Republic (e-mail: jxd@jxd.cz); (1) https://orcid.org/0000-0001-8402-6125

ABSTRACT: The first occurrence of Helix lucorum Linnaeus in the Czech Republic was reported 12 years ago, at the closed train station Žižkov in Prague. A part of the station is a ruderal habitat while large patches are covered with partly damaged concrete. At the site where it was first recorded, and where the density of $H$. lucorum is still the highest, this invasive snail has now almost completely replaced the original $H$. pomatia Linnaeus. However, it has not expanded either inside or outside the station area.

KEY WORDS: invasive species; Helix lucorum; Prague; Czech Republic

\section{INTRODUCTION}

Helix lucorum Linnaeus, 1758 (Eupulmonata, Helicidae) is an invasive species. It was first recorded in Prague in 2008, within the urban heat island, at the closed train freight station Žižkov (HORSÁK et al. 2010). The species was reported from the same locality four (PELTANOVÁ et al. 2012a) and ten years later (KORÁBEK et al. 2018). Currently, H. lucorum is included in the Czech Republic check-list and in the distribution maps of the molluscs of the Czech and Slovak Republics (HORSÁK et al. 2021).

The species is native to Anatolia, and to the southern and eastern Balkans; at present it is widespread in southern Europe, with the range extending from Spain to eastern Turkey (WELTER-SCHULTES 2012). It is assumed that it does not form subspecies. The Crimean form of $\mathrm{H}$. lucorum is not regarded as a subspecies, but as a conchologically distinct population (KORÁBEK et al. 2018).

The reported expansion of $H$. lucorum reflects the general trend of northward spread of originally south- ern snails. Over the last thirty years, the number of non-native species of terrestrial snails in the Czech Republic has increased from 5 to 15 (8\% of all species); more than half of them are of Mediterranean origin. Since 2000, seven new non-native species (six of them Mediterranean) have been recorded. This trend reflects the global warming and the increase in the intensity of foreign trade over the past six decades, suggesting a synergistic effect of climate conditions and socio-economic factors on snail expansion (Peltanová et al. 2012b).

H. lucorum is spreading throughout Europe. It was recorded, among other countries, in Hungary (VARGA et al. 2010), in Slovakia (ČEJKA \& ČAČANÝ 2014) and in Russia (Moscow; EgOrov 2017). The aim of this study was to check if the local population of $H$. lucorum, recorded for the first time 12 years ago, had spread from its initial locality at the closed railway station Žižkov and expanded to the nearby green areas.

\section{MATERIAL AND METHODS}

The closed railway station Žižkov is surrounded by walls and busy asphalted roads, but at one point on its eastern side it is connected to the nearby undeveloped areas by a strip of wasteland (Fig. 1), with 


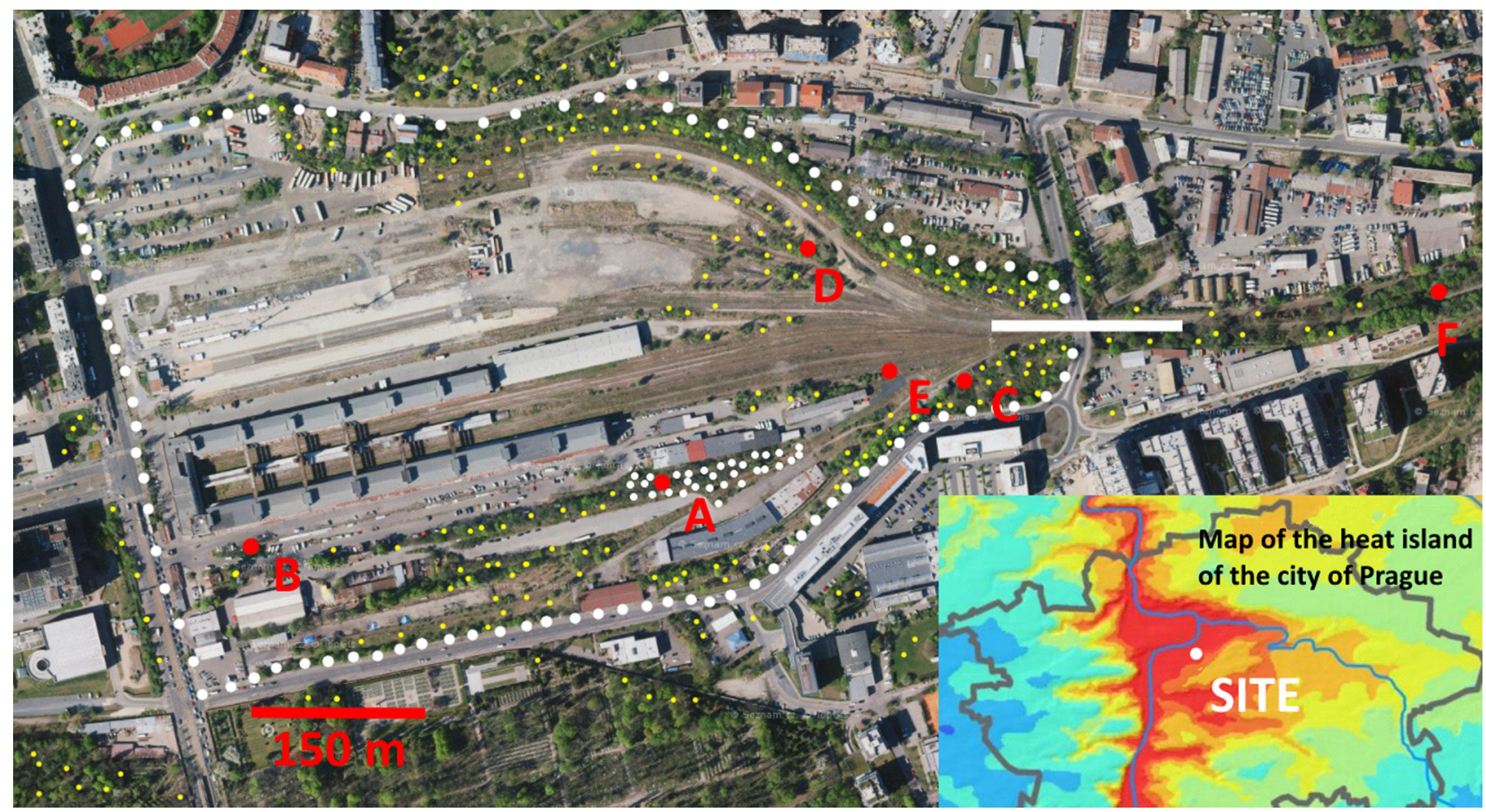

Fig. 1. Closed railway station Žižkov. The station boundary indicated with large white dots. The wide white line denotes the potential bio-corridor. Sites A-F indicated in red. The patch with high density of H. lucorum marked with small white dots. Yellow dots mark searched spots within and outside the station. Inset shows a map of Prague's heat island (ČESKÝ HYDROMETEOROLOGICKÝ ÚSTAV 2010), white dot in its centre - Žižkov railway station

soil only sparsely covered with herbage along the railway tracks (not used for decades). This strip of undeveloped land may serve as a bio-corridor.

To monitor the spread of H. lucorum, I used the Mumladze method which I modified (MUMLADZE 2013). During a tour in September 2018, in the centre of the Žižkov station, I found a spot which was favourable for molluscs. Most of the station's space is concrete-covered. Snails can only be found in a few places where the vegetation patches are close to the crumbling buildings and the terrain tends to be rugged. At site A, in the summer I found a high density of snails, not only $H$. lucorum, but also smaller helicids, such as the common Cepaea nemoralis (Linnaeus, 1758).

Other collections took place during the dormant period from the beginning of winter to early spring, when the soil was visible. During the growing sea- son, the soil, especially around site A, is covered with dense leaves of herbs, and the snails are difficult to find. After the leaves have fallen, it is much easier to find empty shells. In the spot where I observed (in both summer and winter) the highest density of $H$. lucorum (site A), I collected all the empty shells of Helix from a $10 \times 10$ metres plot, and counted the number of shells of $H$. lucorum and $H$. pomatia Linnaeus, 1758.

I used the same method in the other sites, and collected all the shells of the genus Helix from $10 \times 10$ metres plot in each. I also chose one place (a recently abandoned landfill) outside the station site F. Besides, I searched the entire area of the station and its close surroundings (not only sites A-E and F) and collected shells of the genus Helix during the winter/early spring between 2018 and 2021.

\section{RESULTS}

During its 12 years of occurrence, $H$. lucorum spread neither through the closed station, nor outside it (Fig. 1). It was only found in larger numbers in a patch of a few hundred square metres (site A and nearby). In this area, it significantly outnumbered the native $H$. pomatia. The numbers of shells of $H$. lucorum and $H$. pomatia in the surveyed sites are shown in Table 1.
Table 1. Numbers of Helix shells found in the surveyed sites

\begin{tabular}{cccc}
\hline Site & Geographical coordinates & H. pomatia & H. lucorum \\
\hline A & $50^{\circ} 05.06^{\prime} \mathrm{N}, 14^{\circ} 28.63^{\prime} \mathrm{E}$ & 6 & 83 \\
$\mathrm{~B}$ & $50^{\circ} 05.03^{\prime} \mathrm{N}, 14^{\circ} 28.34^{\prime} \mathrm{E}$ & 4 & 12 \\
C & $50^{\circ} 05.11^{\prime} \mathrm{N}, 14^{\circ} 28.86^{\prime} \mathrm{E}$ & 2 & 4 \\
$\mathrm{D}$ & $50^{\circ} 05.17^{\prime} \mathrm{N}, 14^{\circ} 28.74^{\prime} \mathrm{E}$ & 0 & 1 \\
E & $50^{\circ} 05.13^{\prime} \mathrm{N}, 14^{\circ} 28.66^{\prime} \mathrm{E}$ & 0 & 1 \\
$\mathrm{~F}^{*}$ & $50^{\circ} 05.15^{\prime} \mathrm{N}, 14^{\circ} 29.20^{\prime} \mathrm{E}$ & 20 & 0 \\
\hline
\end{tabular}

* - outside the station. 


\section{DISCUSSION}

There are at least four mechanisms of passive dispersal of terrestrial molluscs: anemochory, hydrochory, zoochory and anthropochory (KRAMARENKO 2014). The expansion involves two distinct spatial scales: transcontinental and intra-continental. Most transcontinental expansions are cases of spread of European species to Africa, the Americas and Australia. Outside Europe, H. lucorum was found in North America, northern Africa and China (GBIF SECRETARIAT 2019). It was also recorded in Uzbekistan (IZZATULAYEV 2013). In Europe this synanthropic species, besides accidental passive dispersal, was also introduced intentionally for commercial purposes and now it is regarded as one of the most conspicuous snail newcomers in Eastern, Central and Western Europe (MIENIS \& RITTNER 2010, KORÁBEK et al. 2018). Its colonies in Prague and Moscow survived inside the city heat islands (EGOROV 2017). Now it is common in Budapest where the populations were established in the last 30 years (PÁLLGERGELY et al. 2019). In France, besides the heat island of Paris, H. lucorum occurs in the south of the country (MUSÉUM NATIONAL D'HISTOIRE NATURELLE (Ed.) 2003-2021). In northern Greece the activity of $H$. lucorum is primarily controlled by humidity, while temperature and photoperiod affect the activity only when days are long and cool or short and hot (LAZARIDOU-DIMITRIADOU \& SAUNDERS 1986).

Although the introduced population of $H$. lucorum has inhabited the locality for twelve years and it now outnumbers the native $H$. pomatia, it is not expanding any further, therefore in Prague it currently does not meet the criteria of an invasive species.

$H$. pomatia was found to prefer habitats with the smallest possible difference between the air temper-

\section{REFERENCES}

ČEJKA T., ČAČANÝ J. 2014. The first record of the Turkish snail (Helix lucorum L., 1758) in the Slovak Republic. Malacologica Bohemoslovaca 13: 124-125.

ČESKÝ HYDROMETEOROLOGICKÝ ÚSTAV 2010. Thermal map of Prague. Available on the request from ČHU at https://www.chmi.cz/.

EGOROV R. 2017. Helix lucorum lucorum Linnaeus, 1758 (Pulmonata, Helicidae) in the city of Moscow. Malacologica Bohemoslovaca 16: 28-32.

GBIF SECRETARIAT 2019. GBIF Backbone Taxonomy. Checklist dataset. https://doi.org/10.15468/39omei

HORSÁK M., ČEJKA T., JUŘIČKOVÁ L., BERAN L., HORÁČKOVÁ J., HLAVÁČ J. Č., DVOŘÁK L., HÁJEK O., DivíŠEK J., MAŇAS M., LOŽEK V. 2021. Check-list and distribu- ature and the temperature of the substratum (Voss et al. 2001). This may limit the accessibility of the bio-corridor to snails and thus explain the absence of any Helix in certain parts of the station. In the northern and eastern parts of the station large patches of concrete cover the ground; they may cause frequent temperature differences between air and subsoil.

The population of $H$. lucorum lives only in a narrow, broken strip of greenery, but it does not spread even within the area, where there are no physical barriers to dispersal. Therefore, the dry substrate in most of the area can be regarded as a very likely limiting factor. A long dry strip of land in the eastern end of the station, of about two hundred and fifty metres, apparently prevents $H$. lucorum from penetrating the potential bio-corridor with wet vegetation along the railway tracks. This indicates that the expansion-preventing factors are rather local, associated with the microclimate of the locality. H. lucorum should still be regarded as a potentially invasive species.

\section{ACKNOWLEDGEMENTS}

I would especially like to thank Associate Professor LUCIE JUŘIČKOVÁ (Charles University, Prague, Czech Republic) for a very kind repeated consultation, when she gave me, albeit a layman, her time and answered my probably very stupid questions. She also informed me about the colony of H. lucorum in Prague. I would also like to thank Associate Professor LEVAN MUMLADZE (Ivane Javakhishvili State University, Tbilisi, Georgia) for his kind consultations and explanations of his work on $H$. lucorum, which was a valuable guide to me and whose method I used.

tion maps of the molluscs of the Czech and Slovak Republics, checklist updated at January 12, 2021, maps updated at January 24, 2021.

Horsák M., JUŘičKOVÁ L. BERAN L., ČEJKA T., DVOŘÁK L. 2010. Komentovaný seznam měkkýšů zjištěných ve volné přírodě České a Slovenské republiky. Annotated list of mollusc species recorded outdoors in the Czech and Slovak Republics. Malacologica Bohemoslovaca Supplement 1: 1-37.

IZZATULAYEV Z. I. 2013. The first record of terrestrial mollusk Helix lucorum (Pulmonata, Helicidae) in Uzbekistan. Vestnik Zoologii 47: 172.

KorÁBEK O., JUŘIČKOVÁ L., BALASHOV I., PETRUSEK A. 2018. The contribution of ancient and modern anthropogenic introductions to the colonization of Europe by 
the land snail Helix lucorum Linnaeus, 1758 (Helicidae). Contributions to Zoology 87: 61-74.

https://doi.org/10.1163/18759866-08702001

KRAMARENKO S. S. 2014. Active and passive dispersal of terrestrial mollusks: a review. Ruthenica 24: 1-14.

LAZARIDOU-DIMITRIADOU M., SAUNDERS D. S. 1986. The influence of humidity, photoperiod, and temperature on the dormancy and activity of Helix lucorum L. (Gastropoda, Pulmonata). Journal of Molluscan Studies 52: $1480-189$.

https://doi.org/10.1093/mollus/52.3.180

MiENIS H., RitTNER O. 2010. On the presence of Helix lucorum Linnaeus, 1758 (Mollusca, Gastropoda, Helicidae) in Le Vesinet, a western suburb of Paris. MalaCo 6: 266-267.

MuMLADZE L. 2013. Shell size differences in Helix lucorum Linnaeus, 1758 (Mollusca: Gastropoda) between natural and urban environments. Turkish Journal of Zoology 37: 1-6. https://doi.org/10.3906/zoo-1206-10

MusÉUM NATIONAL D'Histoire NATURELle (Ed.) 2003-2021. National Inventory of Natural Heritage. Available online at https://inpn.mnhn.fr/espece/cd nom/199869? lg=en (accessed 20 April 2021).

PÁll-Gergely B., Majoros G., Domokos T., JuhÁsz A., TuRÓCI Á., BADACSONYI L., FEKETE J., AsAMI T. 2019. Realtime Social Networking Service rapidly reveals distributions of nonindigenous land snails in a European capital. BioInvasions Records 8: 782-792. https://doi.org/10.3391/bir.2019.8.4.06
Peltanová A., Petrusek A., KMENT P., JuŘičKovÁ L. 2012a. A fast snail's pace: colonization of Central Europe by Mediterranean gastropods. Biological Invasions 14: 759-764. https://doi.org/10.1007/s10530-011-0121-9

PELTANOvÁ A., DVoŘÁK L., JUŘIČKOVÁ L. 2012b. The spread of non-native Cepaea nemoralis and Monacha cartusiana (Gastropoda: Pulmonata) in the Czech Republic with comments on other land snail immigrants. Biologia 67: 384-389. https://doi.org/10.2478/s11756-012-0020-2

VARGA A., KiRÁLY G., SULYOK K. M. 2010. A Cornu aspersum (O. F. Müller, 1774) és a Helix lucorum Linnaeus, 1758 adventív csigafajok hazai elofordulásának aktualizálása. Malakológiai Tájékoztató Malacological Newsletter 28: 85-90.

Voss M., UTECHT A., WÜNNENBERG W. 2001. The dependence of thermopreferendum in Helix pomatia L. on air temperature. Journal of Thermal Biology 26: 155-158. https://doi.org/10.1016/S0306-4565(00)00036-X

WELTER-SCHULTES F. W. 2012. European non-marine molluscs, a guide for species identification. Planet Poster Editions, Göttingen.

Received: February 7th, 2021

Revised: March 25th/April 7th/20th, 2021

Accepted: April 27th, 2021

Published on-line: May 11th, 2021 